\title{
Demonstration Gardens in the University of Florida Cooperative Extension Service ${ }^{1}$
}

\section{Eva C. Worden and Cathy J. D'Angelo²}

The Florida Cooperative Extension Service supports several demonstration gardens throughout the state. These gardens showcase plants and sustainable landscape horticulture techniques appropriate to local areas and are open to the community free of charge. They provide learning opportunities for home gardeners and landscape professionals on design, planting and maintenance procedures. Several gardens have interpretive materials available to interested visitors including signage, brochures, and self-guided tours. Some gardens host functions such as family festivals, plant seminars, and sales that attract large audiences. Most of the gardens are maintained by Master Gardeners, under the supervision of county extension faculty and some gardens use salaried staff. One county offers training to youth from a local Sheriffs farm, that provides some of the labor.

Gardens typically are stocked with plants grown in shade houses or greenhouses by Master Gardeners. Plant material also is obtained by donations from local nurseries, research and education centers, and horticultural organizations.
Funding for development and maintenance of the gardens may be obtained from state, county, or city sources, county and regional water authorities, and private industry. Philanthropic donations, memberships, sponsorships, and other naming and funding opportunities provide additional funds for some of the gardens.

Principles of the Florida Yards and Neighborhoods (FYN) environmental landscape management extension program are demonstrated in many of the gardens. The Florida-friendly landscaping approach emphasizes nine major principles including: "right plant, right place", water efficiently, fertilize appropriately, mulch, attract wildlife, control yard pests responsibly, recycle, reduce storm water runoff, and protect the waterfront. More information on FYN can be obtained at http://hort.ufl.edu/fyn.

Listed below are the demonstration gardens of the University of Florida's Cooperative Extension Service, with photographs of selected facilities. Each garden listing is linked to a web page where further information is available.

1. This document is ENH 865, one of a series of the Environmental Horticulture Department, Florida Cooperative Extension Service, Institute of Food and Agricultural Sciences, University of Florida. Original publication date June 12, 2002. Visit the EDIS Web Site at http://edis.ifas.ufl.edu.

2. Eva C. Worden, Assistant Professor and Extension Specialist, Fort Lauderdale Research and Education Center; Cathy J. D'Angelo, Extension Program Assistant.

The Institute of Food and Agricultural Sciences (IFAS) is an Equal Employment Opportunity - Affirmative Action Employer authorized to provide research, educational information and other services only to individuals and institutions that function without regard to race, creed, color, religion, age, disability, sex, sexual orientation, marital status, national origin, political opinions or affiliations. For information on obtaining other extension publications, contact your county Cooperative Extension Service office. Florida Cooperative Extension Service / Institute of Food and Agricultural Sciences / University of Florida / Larry R. Arrington, Interim Dean 


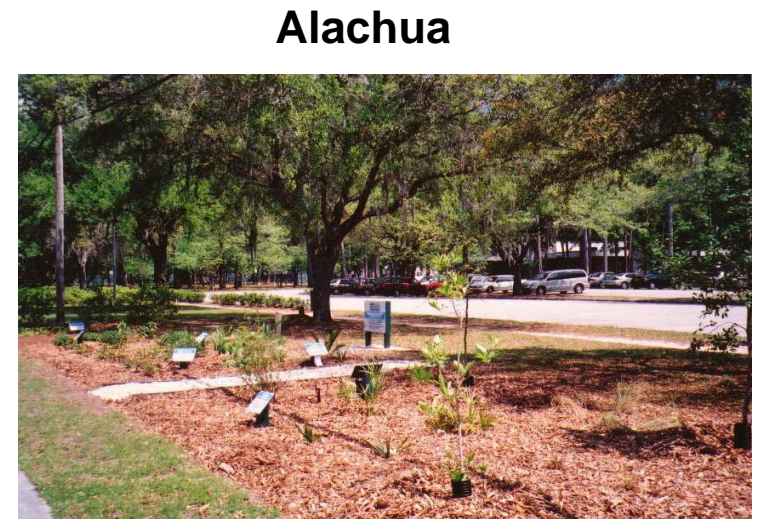

Figure 1. Alachua County Extension Garden

Alachua County Extension/City of Gainesville Garden

$34^{\text {th }}$ St and $8^{\text {th }}$ Ave.

Gainesville, Florida 32609-2658

(352) 955-2402

SUN: $625-2402$

\section{http://alachua.ifas.ufl.edu}

This Florida friendly, drought-tolerant garden is a joint effort between the City of Gainesville and the Alachua County Extension Office. Located in a city park on the corner of $34^{\text {th }}$ St. and $8^{\text {th }}$ Ave., the garden is maintained by county Master Gardeners and affiliated with Florida Yards and Neighborhoods (FYN).

\section{Brevard}

Brevard County Extension Xeriscape Garden

3695 Lake Dr.

Cocoa, Florida 32926-8699

(407) 633-1702

\section{http://brevard.ifas.ufl.edu/Horticulture/}

This xeriscape garden demonstrates the principles of FYN. Completed in 1997, it is maintained by Master Gardeners and the Native Plant Society.

\section{Charlotte}

Charlotte County Mixed Demonstration Garden and Tropical Fruit Tree Collection

7000 Florida St.

Punta Gorda, Florida 33950

(941) 764-4340

\section{http://charlotte.ifas.ufl.edu/mg.htm}

Organized in 1992, this fenced garden consists of sixteen raised bed plots that are maintained by individual Master Gardener volunteers. Includes: native plants, roses, herbs, pineapples, cacti/succulents, vegetables, perennial peanuts, demonstration grasses, and a butterfly plot. Tropical fruit trees are grown outside the main fenced area.

\section{Clay}

Clay County Extension Shade Garden

2463 State Road 16 West

Green Cove Springs, Florida 32043-0278

(904) 284-6355

SUN: $827-1355$

\section{http://clay.ifas.ufl.edu}

Features include: native plants, herbs, a butterfly garden, a demonstration beehive and a demonstration wildlife habitat with low volume irrigation that follows the principles of FYN.

\section{Collier}

Southwest Florida Horticultural Learning Center

14700 Immokalee Road

Naples, Florida 34120-1468

(941) 353-4244

SUN: $974-5098$

http://collier.ifas.ufl.edu/Master\%20Gardener/ comegrow.htm 
Based on FYN principles, this garden was developed adjacent to the Collier County Extension Service building to support outdoor educational programs in horticulture, gardening, landscape design, and natural resource management. When complete, it will include four acres of small space theme gardens including: a recycling and vegetable garden, a citrus garden, a garden of the senses, a 4-H children's learning garden, a courtyard garden, an aquatic garden, a salt-tolerant garden, a cold-tolerant garden, a tropical ornamental garden, a native plant garden, a xeriscape garden, a color display garden, a ground cover garden and a perennial peanut trial area.

\section{Columbia}

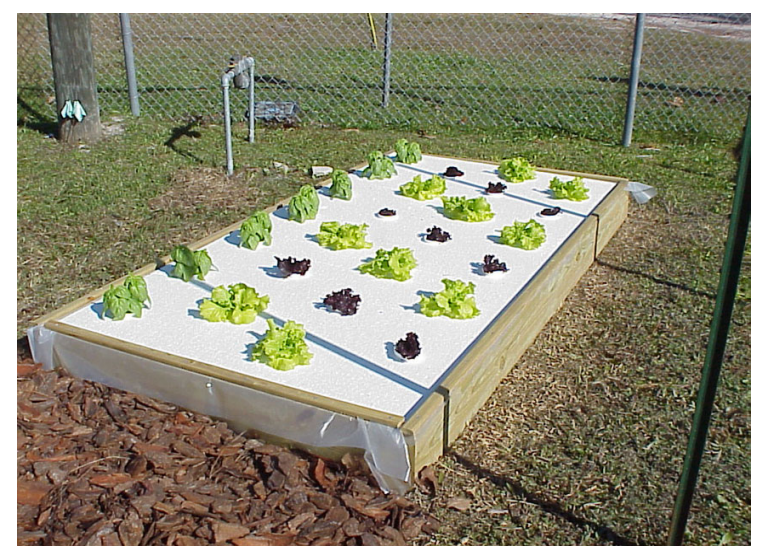

Figure 2. Vegetable plot in Columbia County Extension Garden

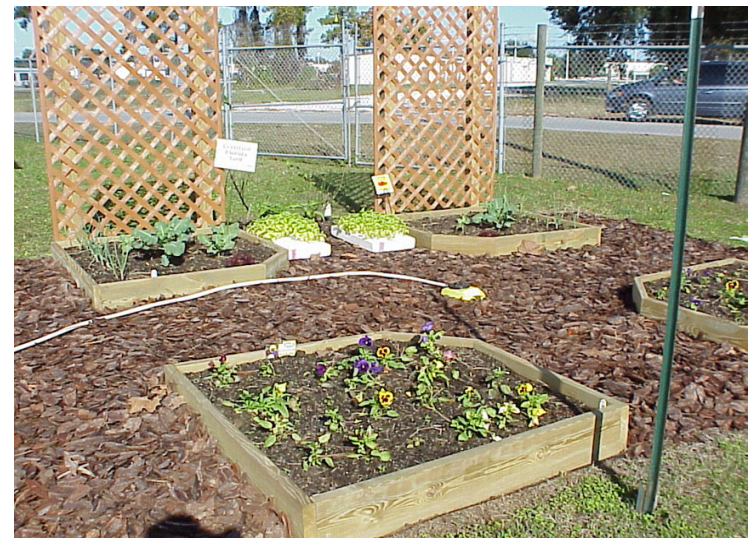

Figure 3. Trellis system in Columbia County Extension Garden

Columbia County Demonstration Garden

Route 18, Box 720

Lake City, Florida 32025

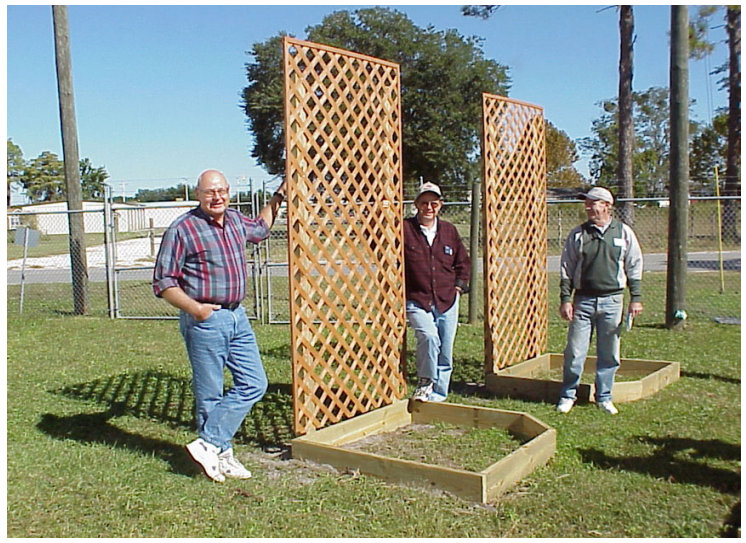

Figure 4. Master Gardeners and Don Goode, Columbia County Agent in the Columbia County Extension Garden

(386) $752-5384$

SUN: $839-1030$

\section{http://columbia.ifas.ufl.edu}

Master Gardeners and 4-H youth maintain a mixture of seasonal flowers and vegetables with a hydroponic bed, four raised beds and a trellis system. Mist irrigation is demonstrated.

\section{Escambia}

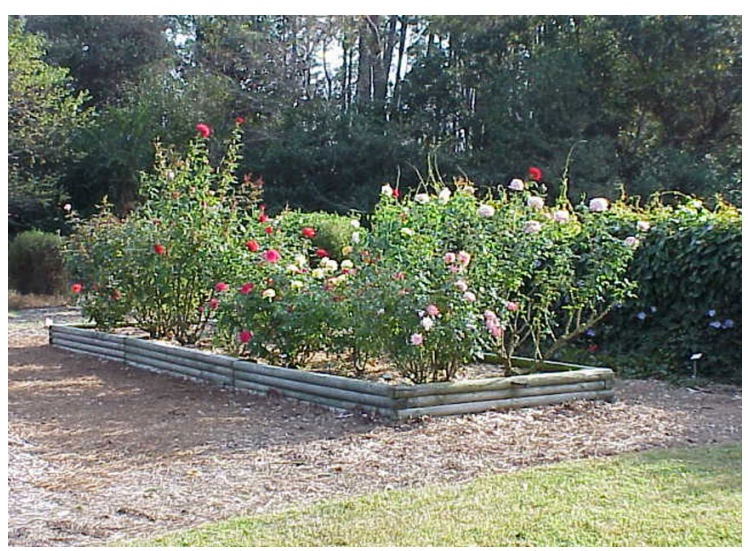

Figure 5. Roses in Escambia County Extension Garden

Escambia County Extension Garden

3740 Stefani Road

Cantonment, Florida 32533-7792

(850) 475-5230

SUN: $690-5230$

\section{http://escambia.ifas.ufl.edu/}




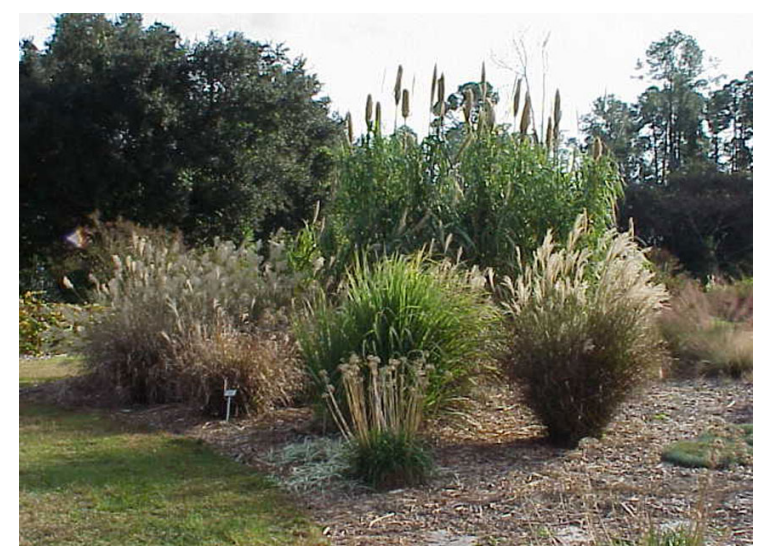

Figure 6. Grasses in Escambia County Extension Garden

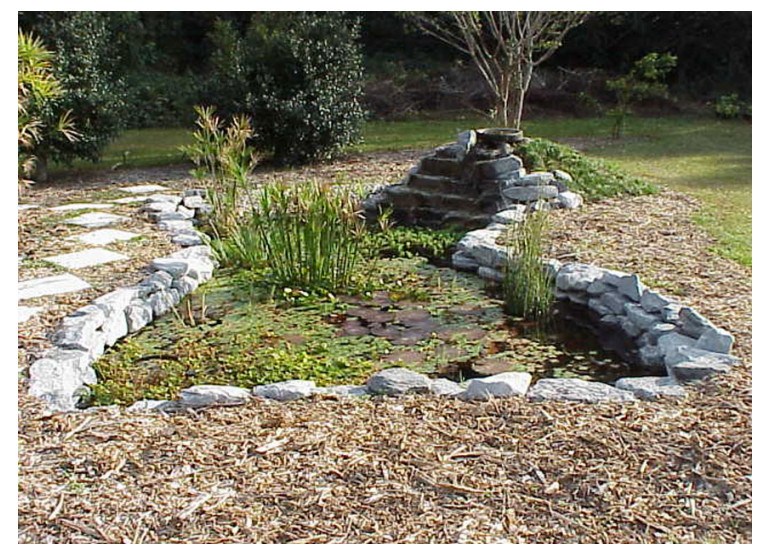

Figure 7. Extension Water Garden in Escambia County

A joint effort between the Escambia County Master Gardeners and local vocational technical school, the garden features eleven areas including: vegetables, roses, native plants, ornamentals, day lilies, mulches, bogs and grasses.

\section{Highlands}

Highlands County Extension Garden

4509 George Blvd.

Sebring, Florida 33875

(863) 402-6544

SUN: 718-6540

\section{http://highlands.ifas.ufl.edu/}

Located adjacent to the extension building, the county courthouse and office buildings, Master Gardeners from Highlands county use native plants to illustrate the principles of xeriscape gardening.

\section{Hillsborough}

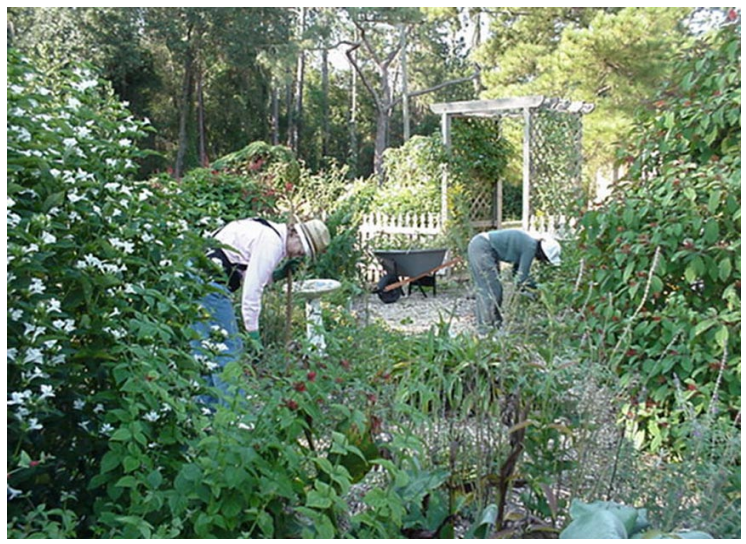

Figure 8. Master Gardeners in the Hillsborough County Extension Garden

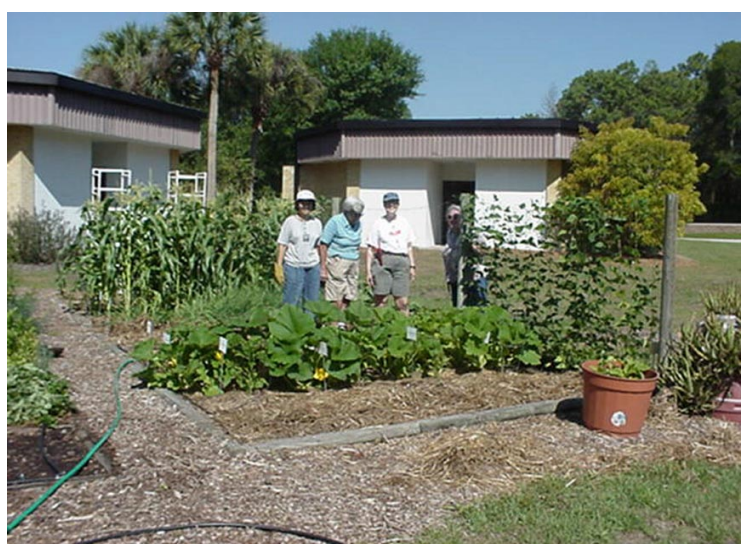

Figure 9. Master Gardeners in the Hillsborough County Extension Vegetable Garden

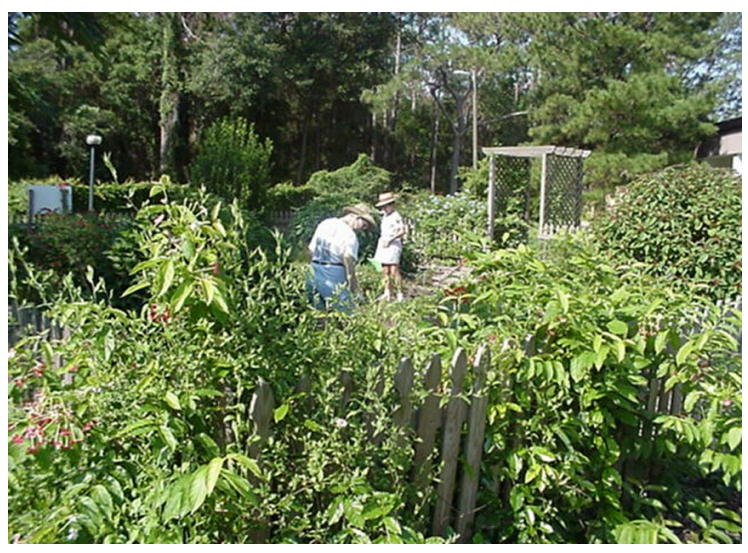

Figure 10. Hillsborough County Extension Garden

Hillsborough County Extension Garden

5339 County Road 579

Seffner, Florida 33584 
(813) 744-5519

SUN: 541-5772

\section{http://Hillsboroughcounty.org}

Maintained by Master Gardeners, this garden features a small arboretum of native trees along with a fruit and spice park, an antique rose garden, an organic vegetable and herb garden, a perennial butterfly garden, and a ground cover demonstration that illustrates drip irrigation. A compost and mulch demonstration and a native plant garden also are featured.

\section{Indian River}

Indian River Extension Color Garden

1028 20th Place, Suite D

Vero Beach, Florida 32960

(561) 770-5030

SUN: $268-5030$

\section{http://indian.ifas.ufl.edu/}

Illustrating different uses of color and texture through plant materials, these landscapes are located at the County Extension office, maintained by Master Gardeners and associated with FYN.

\section{Lake}

Lake County Horticultural Learning Center

30205 State Road 19

Tavares, Florida 32778-4262

(352) $343-4101$

\section{http://discoverygardens.ifas.ufl.edu/}

The Learning Center is situated on a 4.5 acre site with a one acre plant evaluation area and a 3.5 acre public garden called Discovery Gardens. The garden includes 20 theme/display gardens, each designed to show a different gardening aspect in central Florida. There are more than 600 different plants demonstrating how homeowners can achieve the landscape they want. The plants are labeled and cultural information is available upon request at the Master Gardner Plant Clinic in the main building. Educational tours and group activities are conducted by trained Master Gardeners called Discovery Tutors. Hands on programs are conducted for area school children utilizing different areas of the Children's Garden. FYN principles are incorporated throughout the gardens. The gardens are open to the public Monday through Saturday from 9:00 a.m. to 4:00 p.m.

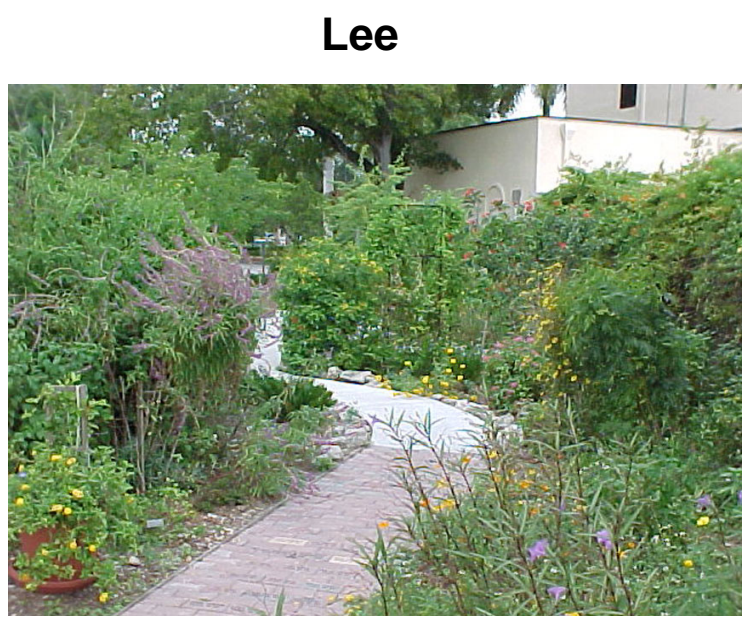

Figure 11. Lee County Extension Garden

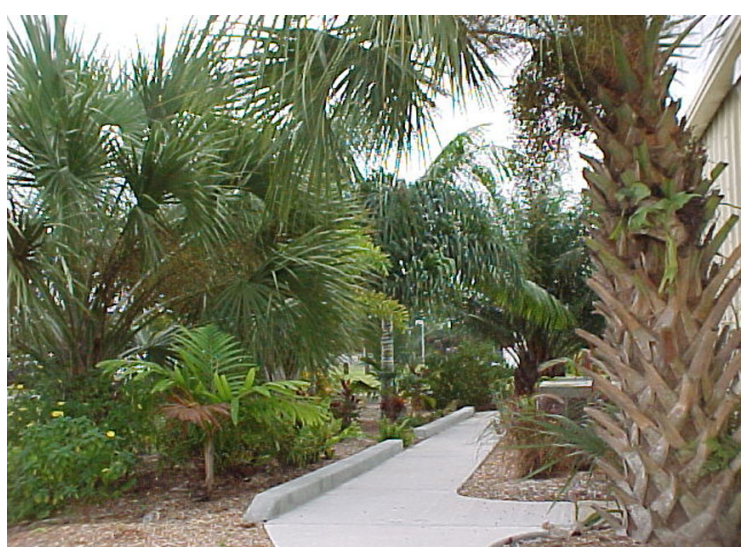

Figure 12. Palms in Lee County Extension Garden

Lee County Extension Gardens

3406 Palm Beach Blvd.

Fort Myers, Florida 33916

(941) 461-7500

SUN: 726-7513

http://www.lee-county.com/extensionservices 


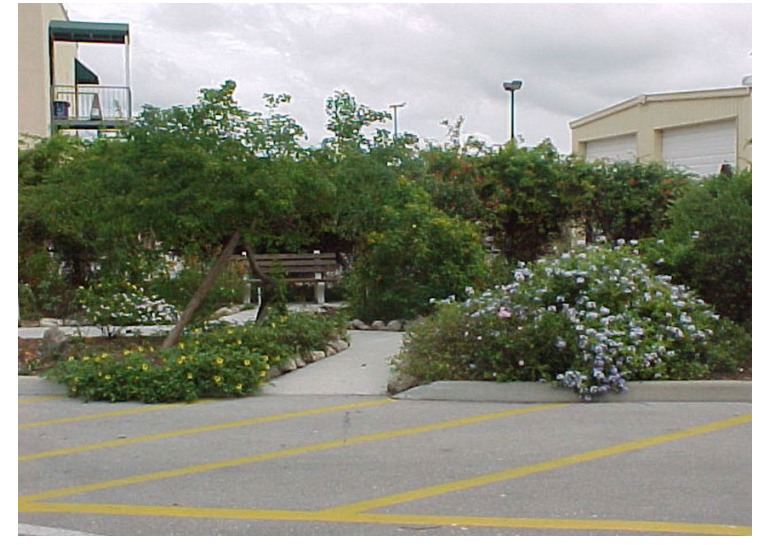

Figure 13. Lee County Extension Garden

Four gardens on the Extension office grounds include: a seasonal vegetable garden, a butterfly garden, a palm garden and a grape arbor. They are maintained by Master Gardeners.

\section{Leon}

Leon County Demonstration Garden

Leon County Agricultural Center

615 Paul Russell Road

Tallahassee, Florida 32301-7099

(850) 487-3004

SUN: $277-3003$

\section{http://leon.ifas.ufl.edu/}

Using the principles of FYN and located on the Extension grounds, this garden includes native plants, wildflowers, perennials and vines. An arboretum is being developed.

\section{Manatee}

Manatee County FYN Demonstration Gardens

$130317^{\text {th }}$ St. West

Palmetto, Florida 34221

(941) $722-4524$

SUN: $527-3230$

http://manatee.ifas.ufl.edu/

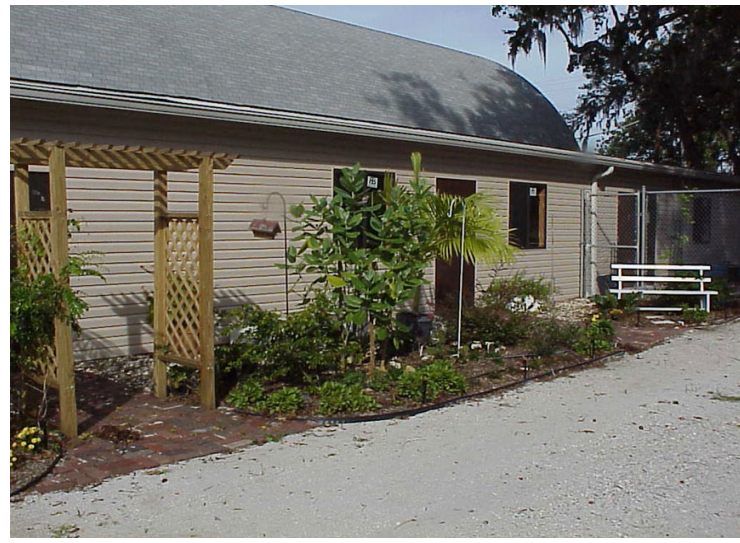

Figure 14. Backdoor at the Manatee County Extension Garden

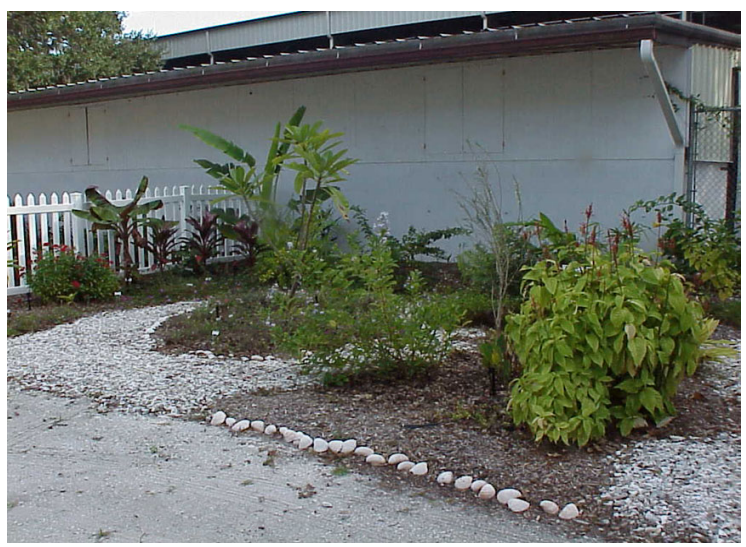

Figure 15. Beach plant area in the Manatee County Extension Garden

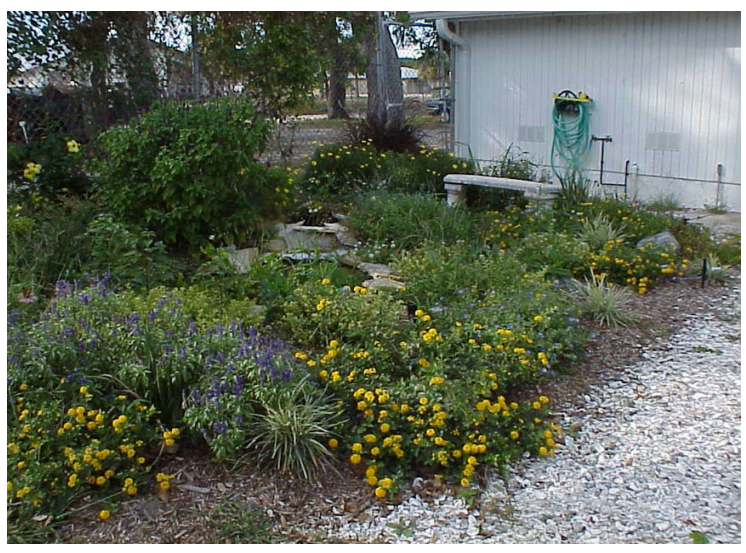

Figure 16. Manatee County Extension Garden

Developed, planted and maintained by Master Gardeners, these gardens include: a beach garden with salt-tolerant and drought-tolerant plants, East and West Manatee gardens with plants that do well in these respective locations, a pond garden, a shade garden, a backdoor garden with edibles and a low-volume irrigation demonstration. 


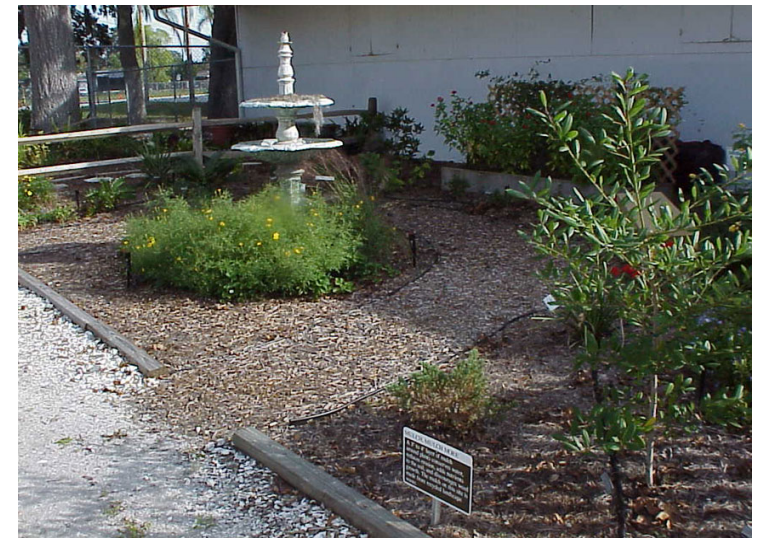

Figure 17. Manatee County Extension Garden

\section{Marion}

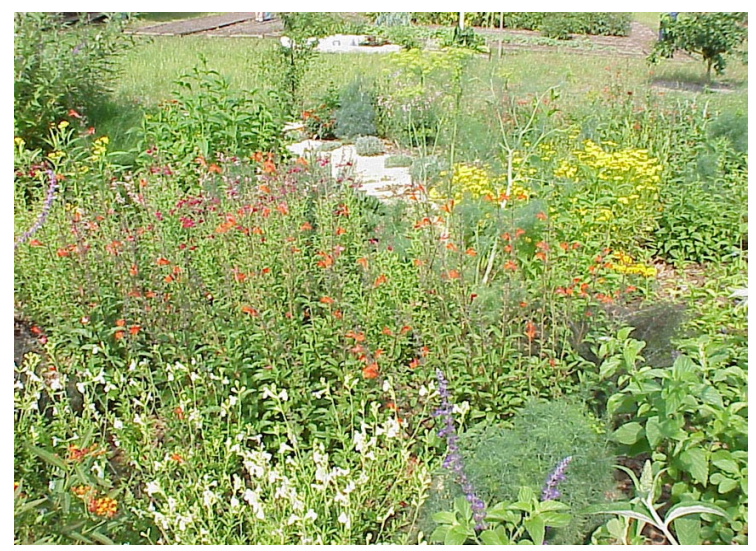

Figure 18. Marion County Demonstration Garden

Taylor Garden

2232 N.E. Jacksonville Rd.

Ocala, Florida 34470-3615

(352) 620-3440

SUN: $667-3440$

\section{http://www.marioncountyfl.org/AC631/ AG_hort_urban.htm}

Located near the Extension office, this .75 acre garden was created and is maintained by Master Gardeners and includes: a butterfly garden, an herb garden, a vegetable garden, an FYN garden and a composting display.

\section{Miami-Dade}

North Miami-Dade Regional Library
2455 NW 183 Street

Carol City, Florida 33056

http://miami-dade.ifas.ufl.edu/

FYN staff and local volunteers created a low-maintenance landscape using drought-tolerant trees, shrubs, perennials and groundcovers.

South Dade Senior High School

28401 SW 167 Avenue

Homestead, Florida 33031

\section{http://miami-dade.ifas.ufl.edu/}

FYN staff, teachers and students used low-maintenance, drought-tolerant shrubs, groundcovers and palms to beautify their school.

Citrus Grove Elementary School

\section{$2121 \mathrm{Nw} 5$ th Street}

Little Havana, Florida 33135

\section{http://miami-dade.ifas.ufl.edu/}

FYN staff, Citizens for a Better South Florida, Hands-On Miami volunteers, staff and teachers from the school planted over 250 native trees, shrubs, palms, cycads, perennials, grasses, and groundcovers to be used by the school in an environmental science curriculum.

\section{Nassau}

Nassau County Extension Butterfly Garden

972 S. Kings Road

Callahan, Florida 32011

(904) 879-1019

\section{http://nassau.ifas.ufl.edu/}

This butterfly garden was established and is currently maintained by Master Gardeners. 


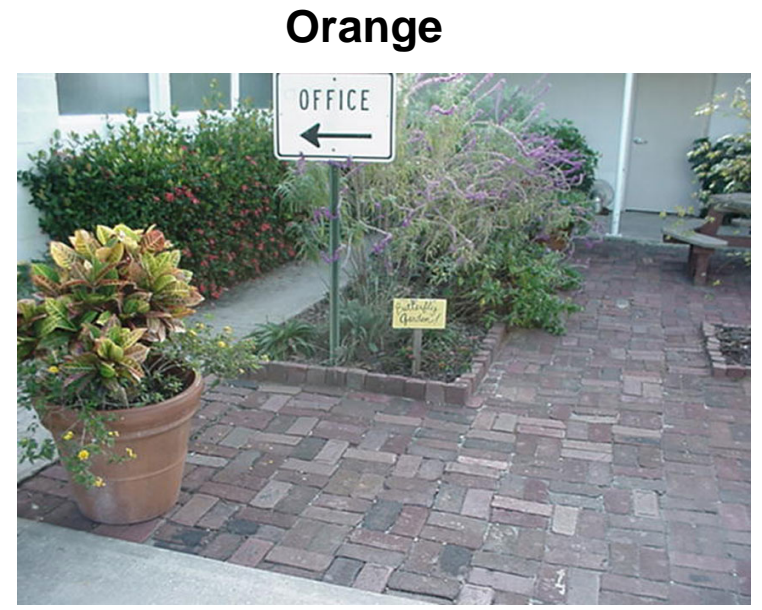

Figure 19. Orange County Extension Garden

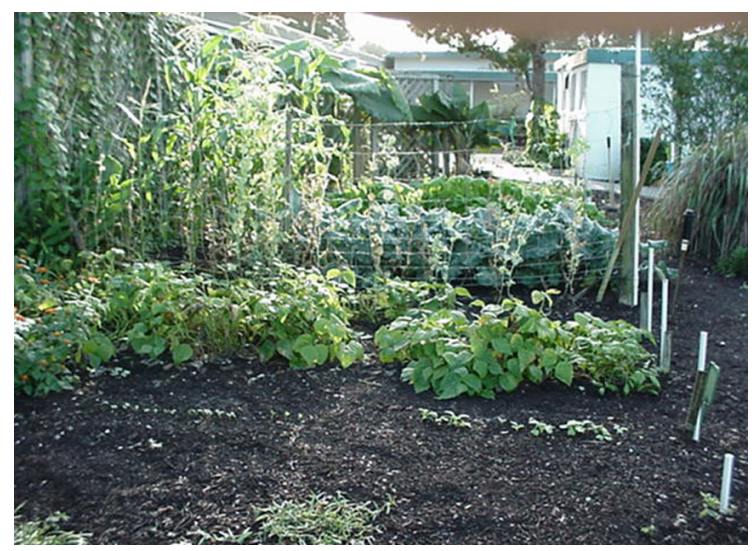

Figure 20. More vegetables in Orange County Extension Garden

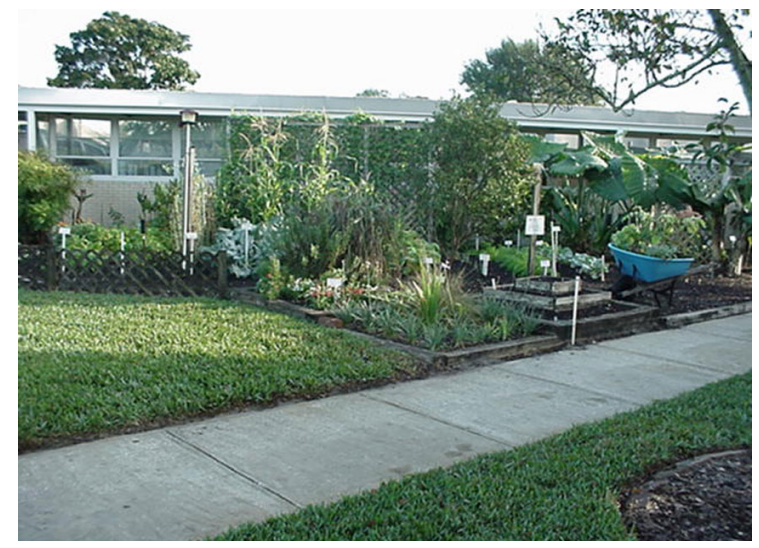

Figure 21. Orange County Extension Garden

Orange County Demonstration Garden

2350 E. Michigan St.

Orlando, Florida 32806

(407) $836-7570$

\section{http://ocextension.ifas.ufl.edu/}

In this garden, Master Gardeners maintain selected vegetables, plants, and flowers to illustrate how to incorporate edible plants in the landscape. A butterfly garden also is included.

Central Florida Fairgrounds Extension Demonstration Garden

4603 W. Colonial Dr.

Orlando, Florida 32808

(407) 295-3247

\section{http://ocextension.ifas.ufl.edu/}

A fenced garden with a playhouse included, this garden is designed with eating in mind. It includes: a raised-bed vegetable garden, peach and apple trees, and herbs and roses. Master Gardeners maintain it and provide guided tours for elementary schools.

\section{Osceola}

Osceola County Extension Garden

Agriculture Center

1901 East Irlo Bronson Highway

Kissimmee, Florida 34744-8947

(407) 846-4181

http://osceola.ifas.ufl.edu/

A landscape and vegetable garden designed and maintained by Master Gardeners and located on the grounds of the extension office.

\section{Palm Beach}

Mounts Botanical Garden

559 Military Trail

West Palm Beach, Florida 33415-1311

Phone: (561) 233-1712 
SUN: $274-1712$

\section{http://palm-beach.ifas.ufl.edu/}

Situated on 14 acres, this garden is the oldest and largest extension garden in Florida. Founded by Red Mounts, a horticulture agent in the 1950s, the garden did not open to the public until the 1970s. Its tropical and subtropical plants include citrus and tropical fruits, palms and vegetables. The garden contains a lake area, a forest area, a begonia and rose collection, a hibiscus garden, a trial garden, and a FYN principles demonstration area.

\section{Pasco}

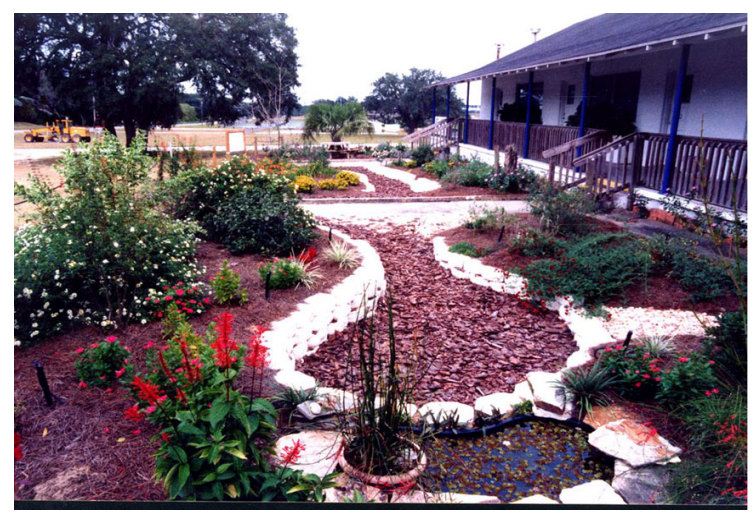

Figure 22. Pasco County Extension Garden

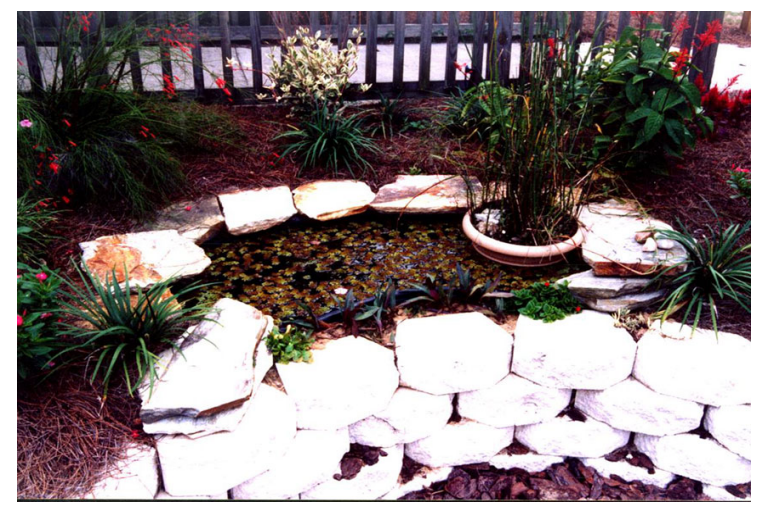

Figure 23. Pasco County Extension Garden

Pasco County Extension Garden

36702 State Road 52

Dade City, Florida 33525-5198

(352) $521-4288$

SUN: 637-4288

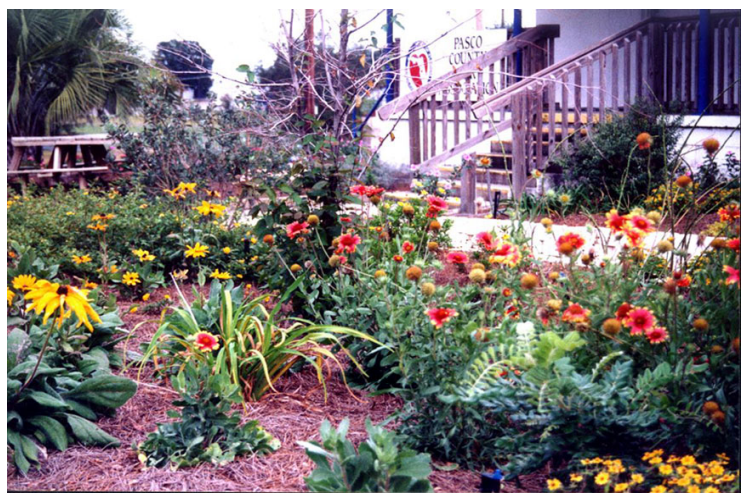

Figure 24. Perennials in Pasco County Extension Garden

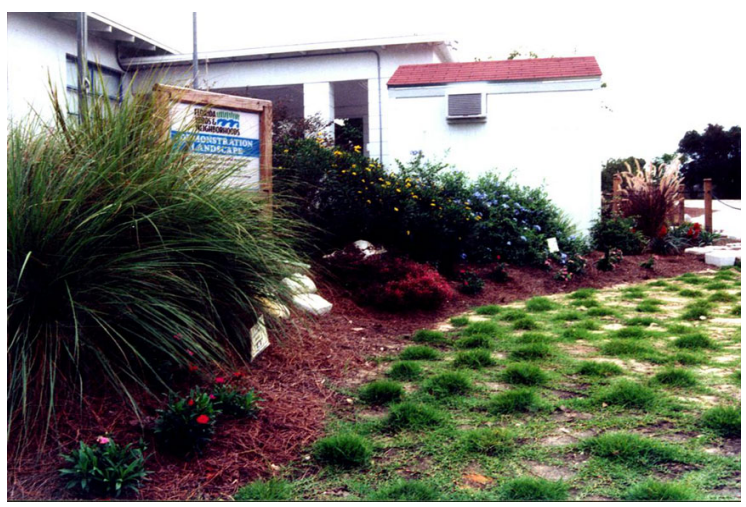

Figure 25. Grasses at the Pasco County Extension Garden

\section{http://pasco.ifas.ufl.edu/}

This FYN demonstration garden, tended by Master Gardeners, features stormwater management with a system of berms, swales, retaining walls, drainage channels, downspouts, and rain barrels. Micro irrigation and different mulches are installed. Butterfly and bird-attracting plants flourish in the garden, complemented by structures designed to attract wildlife, such as ponds, an artificial bog, an old tree trunk, and a large arbor with vines. Homeowners can see many native plants, as well as the new seashore Paspalum turfgrass Sea Isle I, and monitor their progress through the seasons. Visitors may stroll among the plants, read the signs, or just sit on a wall, watch the butterflies, and reflect on the beauty around them.

\section{Pinellas}

The Florida Botanical Gardens

$12175125^{\text {th }}$ St. North

Largo, Florida 33774-3695 
(727) $582-2200$

SUN: 579-2100

\section{http://www.flbg.org/}

Situated on 182 acres that house the Gulf Coast Museum of Art, Heritage Village and the Pinellas County Extension Office, this garden serves over 36,500 visitors a year. Surrounding these facilities are diverse plant environments, which highlight the natural beauty of a Florida setting. Tended by extension Master Gardeners, it includes a heritage palm garden, a jazz garden, a rose garden, a celebration garden, a cottage garden, a topiary garden, a vegetable garden, an herb garden, a tropical walk, a formal wedding garden, and a xeriscape learning center.

\section{St. Lucie}

St. Lucie County Extension Xeriscape Garden

8400 Picos Road, Suite 101

Fort Pierce, Florida 34945-3045

(561) 462-1660

SUN: $259-1660$

\section{http://stlucie.ifas.ufl.edu/}

A mixture of native plants, trees and ornamentals are grouped according to water needs. This garden has FYN affiliation and is maintained by Master Gardeners.

\section{St. Johns}

St. Johns County Extension Arboretum

Cooperative Extension Service

3125 Agricultural Center Drive

St. Augustine, Florida 32092

(904) 824-4564

SUN: $865-2629$

\section{http://stjohns.ifas.ufl.edu/}

This one-acre arboretum includes: trees and shrubs, daylilies, a hydroponics display garden, a test garden and a small vegetable garden. This garden has FYN affiliation and is tended by Master Gardeners.

\section{Santa Rosa}

Milton Demonstration Gardens

5988 Highway 90 Building 4900

P.O. Box 3634

Milton, Florida 32583

(850) 983-2632

\section{http://www.co.santa-rosa.fl.us/santa_rosa/ extension/}

A joint effort between the University of Florida's West Florida Research and Education Center, the Pensacola Junior College and the Master Gardeners of Santa Rosa County Extension, this garden invites visitors to a living classroom where they can identify flowers and shrubs that make up the Florida landscape. Includes: mixed shrubs and perennials, ornamental grasses, ginger and tropical bulbs, ornamental sweet potatoes, bedding plant trials, and a container production area with greenhouses and shade houses.

Panhandle Butterfly House

Navarre Park

Navarre, Florida 32566

(850) 623-6321

\section{http://www.co.santa-rosa.fl.us/santa_rosa/ extension/}

Master Gardeners from three counties created this unique butterfly garden devoted to Florida native butterflies. Open from Memorial Day to Labor Day, this garden shares environmentally friendly gardening with over 12,000 visitors a year. 
Sarasota

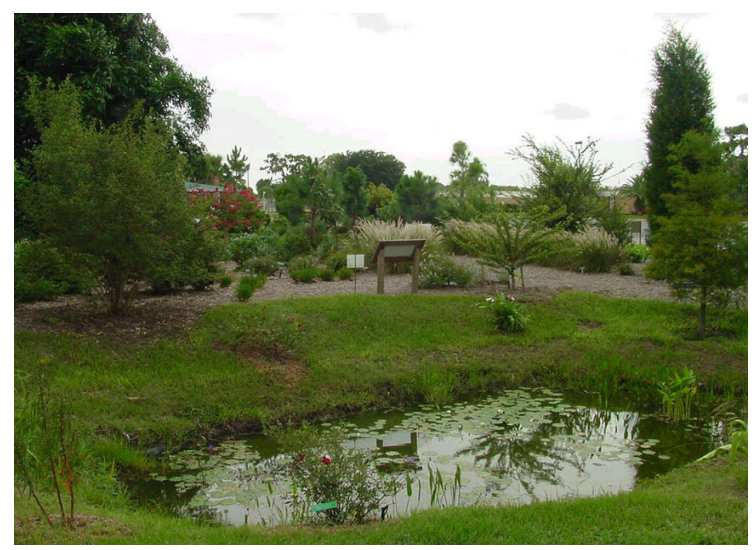

Figure 26. Sarasota County Extension Garden

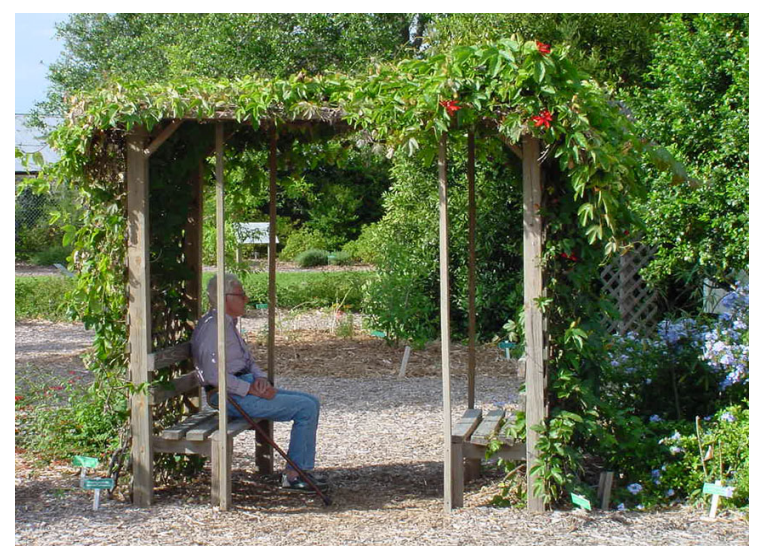

Figure 27. Visitor resting in the Sarasota County Extension Garden

Florida House Learning Center

Sarasota County Technical Institute

4600 Beneva Road South

Sarasota, Florida 34233

(941) 316-1200

\section{http://sarasota.extension.ufl.edu}

This "Model Florida Yard" is the premier FYN demonstration garden in the state showing environmental landscape management principles in design and maintenance. Staffed by Master Gardeners four days per week, the garden includes: wildlife gardening, water gardening, edible landscaping, xeriscaping, micro-irrigation, composting, and plant selections and groupings for particular landscape types in the Suncoast area.

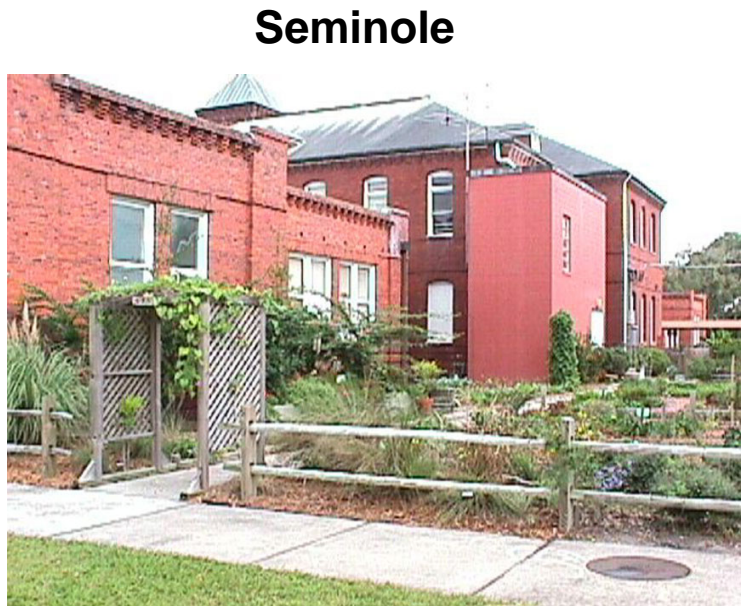

Figure 28. Seminole County Student Museum and Extension Garden

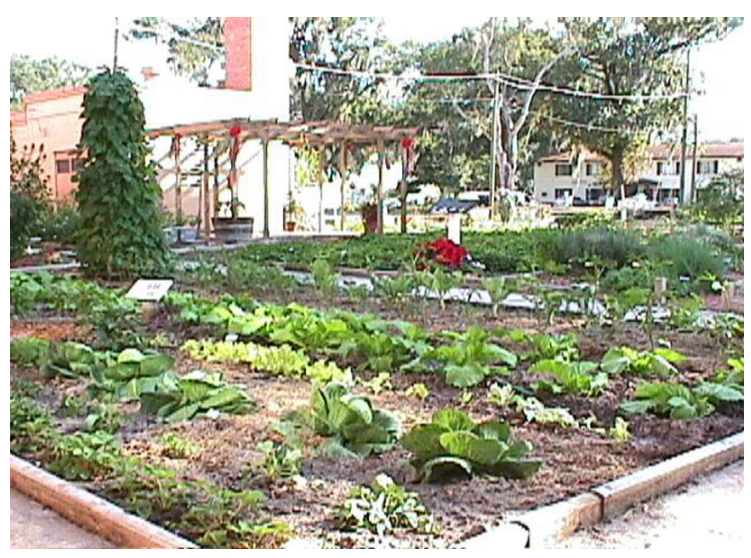

Figure 29. Pioneer Garden at the Seminole County Student Museum and Extension Garden

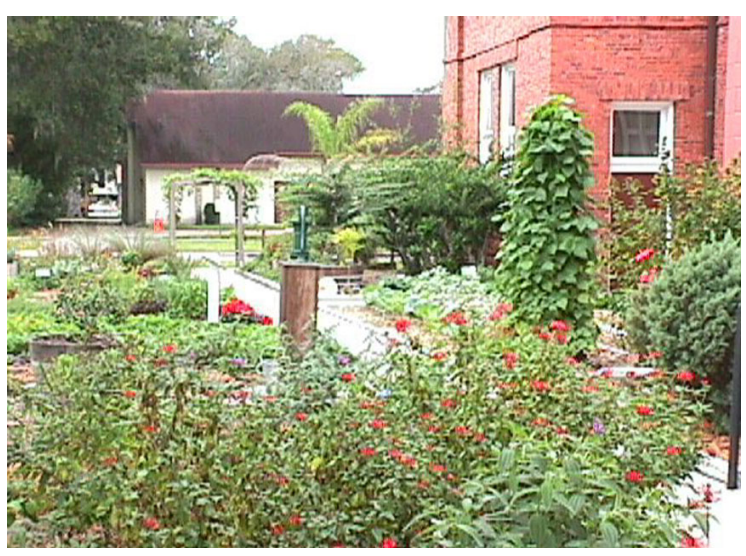

Figure 30. Butterfly Garden at the Student Museum in Seminole County

Demonstration Gardens at the Student Museum 301 West $7^{\text {th }}$ St.

Sanford, Florida 32771 


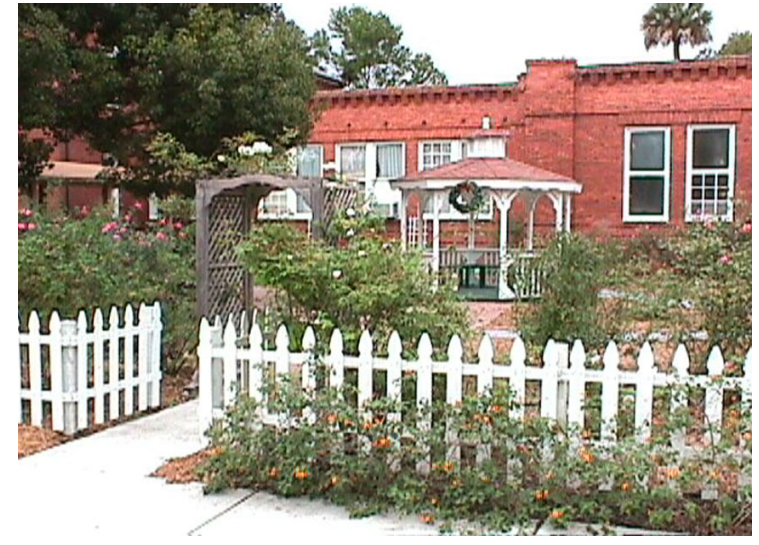

Figure 31. Roses at the Student Museum and Extension Garden in Seminole County

(407) 320-0520

\section{http://www.co.seminole.fl.us/coopext}

A joint venture by Seminole County Extension and the the Student Museum and Social Studies Center of Seminole County Public Schools, this garden is located on the grounds of the Student Museum. Different themes are illustrated including: herbs, pioneer vegetables, pioneer field crops, historic roses, Florida and southeast native plants, shade gardens, tropical gardens, butterfly gardens, muscadine grapes, mints, perennial and annual flower meadows, ornamental grasses, citrus groves and an Oriental raised bed. Maintained by a project team, Master Gardeners and middle school students involved in a pre-baccalaureate program, this garden services approximately 6,000 students who receive instruction from the Museum staff. Also open to the public, the garden was awarded the Florida Master Gardener award of Excellence for best project in 1999.

\section{Sumter}

Sumter County Extension Herb Garden

P.O. Box 218

67 County Road 538

Bushnell, Florida 33513

(352) $793-2728$

http://sumter.ifas.ufl.edu/
Developed and tended by Master Gardeners, this garden is devoted to herbs that grow in Sumter County.

Sumter County Youth Center Garden

841 East $\mathrm{Cr} 48$

Bushnell, Florida 33513

\section{http://sumter.ifas.ufl.edu/}

This is a vegetable and fruit garden used by Master Gardeners to teach gardening skills to the children at the Youth Center.

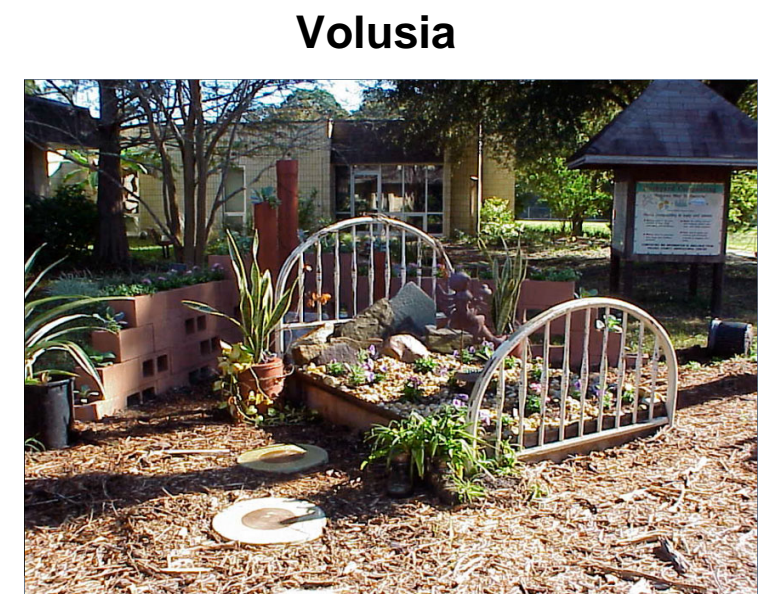

Figure 32. Volusia County Extension Garden

Butterflies in Bloomers Resource Garden

Agricultural Center

3100 E. New York Ave.

DeLand, Florida 32724

(386) $822-5778$

SUN: $377-5778$

\section{http://volusia.org/extension_service}

Primarily a wildlife attracting garden, this garden is a collaboration of the Solid Waste Department and the Volusia County Extension service. It includes a butterfly area, a birdhouse area, a compost alley, and a vegetable garden for the handicapped. It is maintained by Master Gardeners. 